\title{
ШЛЯХИ ПОКРАЩЕННЯ РОБОТИ МЕДСЕСТРИ МАНІПУЛЯЦІЙНОГО КАБIHЕТУ
}

\author{
О. В. Андрієвська, О. П. Мялюк, І. Я. Криницька \\ "Клінічний центр Гемодіаліз", м. Одеса \\ Рівненський державний базовий медичний коледж \\ ДВНЗ «Тернопільський державний медичний університет \\ імені І. Я. Горбачевського МОЗ Украӥни»
}

У статті викладено сучасні дані щодо мотивуючих факторів, що покращать роботу медичних сестер маніпуляційного кабінету.

\section{THE WAYS OF IMPROVING THE WORK OF A NURSE OF THE PROCEDURE ROOM}

\author{
O. V. Andrievska, O. P. Myaluk, I. Ya. Krynytska \\ Clinical Center of Hemodialysis, Odesa \\ Rivne Basic Medical College \\ I. Horbachevsky Ternopil State Medical University
}

The article presents current data on the motivating factors that improve the work of a nurse of a procedure room.

Вступ. Старша медсестра займається управлінською діяльністю в конкретній галузі, тобто $є$ менеджером. Сучасний менеджер повинен бути чесним, порядним, принциповим у всіх питаннях, вміти протистояти тиску як «зверху», так і «знизу», послідовно і твердо стояти на своєму, він повинен володіти організаторськими якостями, діловитістю, енергійністю, тобто здатністю заряджати людей впевненістю, прагненням діяти логічним шляхом, особистим прикладом, власним оптимізмом, повинна бути дисципліна і контроль над собою. Але найголовніше менеджер повинен вміти керувати, організовувати і підтримувати роботу колективу [1, 2].

Діяльність старшої медсестри спрямована на розстановку сил середнього і молодшого медичного персоналу, контроль за якістю його роботи, а також забезпечення належного санітарного стану медичних кабінетів. Старша медична сестра вирішує важливі стратегічні питання, приймає рішення за умов крайньої нестабільності, постійного дефіциту всіх видів ресурсів. Для успішного виконання цих завдань їй недостатньо лише знань в галузі своєї вузької про- фесійної компетенції. Найважливішим критерієм цінності медичної сестри як керівника стаєії управлінська компетентність, лідерські якості, комунікативні здібності, оптимізм, бачення майбутнього і бажання знати завтра те, чого не знаєш сьогодні [3].

Мотивування підлеглих медичних працівників $\epsilon$ непростим завданням, оскільки ситуація ускладнюється специфікою нормативного поля, в якому працюють українські медики [4].

Мета дослідження - проаналізувати якісні характеристики медсестер маніпуляційного кабінету та виявити фактори, що впливають на їх роботу.

Основна частина. Маніпуляційний кабінет займає центральне місце у відділенні, оскільки у ньому виконують маніпуляції, що є невід'ємною частиною лікувального процесу. Висока кваліфікація медичного персоналу та профілактичні асептичні заходи маніпуляційного кабінету дозволяють забезпечити пацієнтам під час проходження процедур безпеку і комфорт. У дослідженні взяли участь 15 маніпуляційних медичних сестер. Кожній із них було задано 11 запитань:

() О. В. Андрієвська, О. П. Мялюк, І. Я. Криницька, 2018

60 ISSN 2411-1597. МЕДСЕСТРИНСТВО. 2018. № 2 
1. Biк:

- 20-30 років;

- 31-40 років;

- 41-50 років;

- 51 i > років.

2. Сімейний статус:

- одружена;

- не одружена;

- розлучена.

3. Наявність дітей:

- так;

- ні.

4. Стаж роботи у відділенні:

5. Освіта:

- закінчена вища;

- незакінчена вища;

- середня спеціальна.

6. Кваліфікаційна категорія:

- вища;

- перша;

- друга;

- немає категорії.

7. Задоволеність роботою:

• цілком задоволені;

- задоволені не повною мірою;

- незадоволені.

8. Задоволеність рівнем заробітної плати:

- цілком задоволені;

- задоволені не повною мірою;

- незадоволені.

9. Виробничі фактори, що негативно впливають на Вас на робочому місці (зазначити декілька):

- фізичні навантаження;

- емоційні навантаження;

- взаємини в колективі;

- вимушені затримки на роботі;

- виконання роботи понад функціональних обов'язків;

- свій варіант.

10. Виробничі фактори, що позитивно впливають на Вас на робочому місці (зазначити декілька):

- улюблена робота;

- прекрасний колектив;

- можливість кар'єрного зростання;

- можливість навчання та підвищення своєї кваліфікації.

11. Які заходи, на Вашу думку, необхідно провести для оптимізації роботи медсестри маніпуляційного кабінету?
За результатами опитування, 40 \% медичних сестер перебувають у шлюбі, 40 \% не перебувають у шлюбі та $20 \%$ - розлучені. У $50 \%$ є діти. За результатами опитування, 30 \% мають стаж роботи у маніпуляційному кабінеті один рік, $20 \%$ - 2 роки, $20 \%$ - 3 роки, 20 \% працюють 7 років, а $10 \%$ - 10 років. Всі медичні сестри мають середньоспеціальну освіту, при цьому один респондент (6,7 \%) має вищу освіту. 70 \% медичних сестер не мають кваліфікаційних категорій, 20 \% - першу і лише 10 \% мають вищу кваліфікаційну категорію. У пункті «Задоволеність роботою» були отримані такі результати: 70 \% медичних сестер не задоволені своєю роботою, а 30 \% цілком задоволені. У наступному пункті «Задоволеність рівнем заробітної плати» результати розподілилися так, що 86,7 \% (13 осіб) медичних сестер не задоволені заробітною платою, а всього лише 2 медсестри 13,3 \% - цілком задоволені. У процесі анкетування вдалося виявити фактори, які, на думку анкетованих, негативно впливають на робочому місці. Отримані наступні результати: $30 \%$ вважають, що негативно впливають на них емоційні навантаження: 30 \% - вимушені затримки на роботі, 50 \% вважають, що фізичні навантаження і 40 \% взаємини в колективі. Наступне питання, дозволило виявити фактори, що позитивно впливають на медичних сестер на робочому місці. На 70 \% медичних сестер позитивно впливає улюблена робота, на 40 \% прекрасний колектив, а на 50 \% - можливість навчання та підвищення кваліфікації. На запитання «які заходи, на Вашу думку, необхідно провести для покращення роботи медсестри процедурного кабінету?» результати розподілилися наступним чином: 86,7 \% (13 осіб) медичних сестер вважають, що необхідно підвищити заробітну плату і по 20 \% вважають, що потрібно підвищити премії і зробити обідню перерву.

При аналізі результатів анкетування, до мотивуючих факторів, що покращать роботу медичних сестер маніпуляційного кабінету, можна віднести наступне: підвищення престижу та пропаганда суспільної значущості професії; популяризація місії медичної сестри; з'ясування потреб і напрямів додаткового матеріального стимулювання працівників (премії, харчування і проїзд, пільгове обслуговування членів сім'і тощо); внесок у розвиток організаційної культури: роз'яснення етичних принципів роботи, сприяння поліпшенню комунікації працівників; створення програм адаптації молодих спеціалістів, вивчення трудової мотивації персоналу методами письмових і усних опитувань, розгалуження посадових обов'язків 
із можливістю поетапного кар'єрного зростання; підвищення самооцінки медичних працівників шляхом усних і письмових подяк, схвалення проявленого професіоналізму, підвищення конкурентоспроможності працівників; профілактика професійного стресу та синдрому професійного вигорання: роз'яснення ефективності психологічних консультацій і психотерапевтичної роботи, навчання персоналу навичкам

\section{СПИСОК ЛІТЕРАТУРИ}

1. Опыт организации контроля качества сестринской деятельности в терапевтическом стационаре / В. В. Масляков, В. А. Левина, И. В. Романова, Н. М. Нехотящая // Фундаментальные исследования. - 2013. № 9-3. - С. 404-408.

2. Самохина Л. П. Роль и место менеджера сестринского дела в организации паллиативной помощи / Л. П. Самохина // Актуальные вопросы управления сестринской деятельностью в системе здравоохранения : материалы Всероссийской научно-практической конференции, антистресової поведінки, проведення соціальнопсихологічних тренінгів; створення комфортних умов праці, контроль за дотриманням правил охорони праці, пожежної безпеки, впровадження здоров'язбережувальних технологій.

Висновки. Важливим критерієм цінності медичної сестри-керівника $є$ їі управлінська компетентність та мотивування підлеглих медичних працівників.

23 сентября 2016 г. - Астрахань : Изд-во Астраханского ГМУ, 2016. - $112 \mathrm{c}$.

3. Павлов Ю. И. Современное состояние сестринского дела и роль медсестры-менеджера в оптимизации системы управления сестринской деятельностью / Ю. И. Павлов, С.В.Лапик // Главная медицинская сестра. 2009. - № 10.

4. Мотивація медичного персоналу на практиці [Електронний ресурс]. - Режим доступу : https://www. medsprava.com.ua/article/488-motivatsya-medichnogopersonalu-na-praktits?from=PW_Auth_organic\&ustp=W 